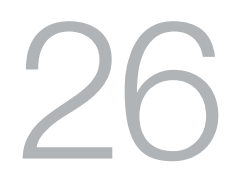

\title{
Consumer Protection, Recreational Activities and Personal Injury Compensation: Inconsistency in Need of Reform
}

\author{
Joachim Dietrich
}

\section{Introduction}

Participation in sport and recreation is one of the most significant causes of personal injury in Australia, including many injuries of a serious nature. The relevant liability rules pursuant to contract, tort and statute therefore constitute a practically important area of law. Despite their importance, however, those rules are not uniform. They are also in parts complex and uncertain. This chapter highlights some of the key difficulties and suggests areas that are in need of reform.

This chapter is mainly concerned with injuries resulting from activities undertaken pursuant to a contract for recreational services (e.g. a paidfor activity such as trampolining). A person negligently injured in the course of the performance of a services contract may sue the defendant supplier of the services for failure to comply with statutory guarantees imposed by the Australian Consumer Law (ACL), among other possible

\footnotetext{
1 My thanks to Iain Field and Pauline Ridge for their helpful comments on earlier drafts. Any remaining errors are solely mine.
} 
claims in contract or negligence. In the absence of a contract, an injured party may proceed only in negligence, against possible defendants such as supervisors of activities, occupiers of premises, etc. Different legal rules may apply accordingly.

Three sources of legal difficulties are highlighted in this chapter:

1. The lack of uniformity as to the available defences under the state and territory ('state') Civil Liability Acts (CLAs), dealing particularly with recreational activities.

2. The interaction between state CLAs laws on negligence and the $A C L$ statutory guarantees in relation to services; and the fact that those different state negligence laws continue to operate despite the 'uniform' $A C L$.

3. The uncertain legal effect of contract clauses that purport to exclude liability for negligently supplied recreational services.

\section{Defences Relevant to Recreational Activities}

As a result of the passage of the various, non-uniform, state CLAs, ${ }^{2}$ we now have eight separate tort law regimes in Australia. There are many differences between the laws in each jurisdiction, but one area in which those regimes differ markedly is in their respective approaches to defences concerning recreational activities.

In four states, plaintiffs engaged in a 'dangerous recreational activity' (DRA) are disentitled from bringing action for harm caused by the 'materialisation' of an obvious risk of that activity. ${ }^{3}$ One focus of litigation has been on the meaning of the qualifying terms 'dangerous recreational activity' (e.g. s 5L CLA (NSW)). A recreational activity is dangerous if it involves a significant risk of harm (s 5K). Importantly, all of 'the particular circumstances in which the activity was being undertaken' are relevant in

2 The titles of the various Acts, like their content, are not uniform. See, for example, Civil Liability Act 2002 (NSW); Wrongs Act 1958 (Vic).

3 See s 5L CLA (NSW), s 19 CLA (Qld), s 20 CLA (Tas), s 5H CLA (WA). 
determining its inherent dangerousness. ${ }^{4}$ It has been held that diving into water of uncertain depth is a DRA; ${ }^{5}$ as is riding a bike on a skate park; ${ }^{6}$ but playing touch football ${ }^{7}$ and calm water cruising ${ }^{8}$ are not.

The term 'obvious risk' is defined broadly in the various provisions as any risks that in the circumstances would have been obvious to a 'reasonable person in the position of' the plaintiff.' There are, however, some differences in the details between jurisdictions. Although the test is objective, the issue is one of whether 'the probability of [the risk's] occurrence is or is not readily apparent to the reasonable person in the position of the plaintiff. ${ }^{10}$ The degree of precision or generality with which one states the 'risk' in question will impact on the conclusion. ${ }^{11}$ For example, what needs to be obvious is more than the end result of an activity - such as falling off a horse - but the manner in which the risk materialised, such as falling off a horse as a result of the saddle slipping. ${ }^{12}$ The courts have drawn subtle distinctions in the interpretation and application of the concepts of 'obvious' risks and 'materialisation' of such risk and the law is complex.

Two jurisdictions only, NSW and WA, have provisions that excuse defendants for any liability arising from risks of recreational activities in respect of which the defendant has given a 'risk warning'. Sections 5M CLA (NSW) and 5I CLA (WA) (which are not identical) are fairly complex and long. Attempts by defendants to rely on them have met with mixed success. ${ }^{13}$ One reason why it may be difficult to rely successfully on these provisions is that a risk warning must be 'given in a manner that is reasonably likely to result in people being warned of the risk before engaging in the recreational activity': s $5 \mathrm{M}(3)$ CLA (NSW); s $5 \mathrm{I}(4)$ $C L A$ (WA).

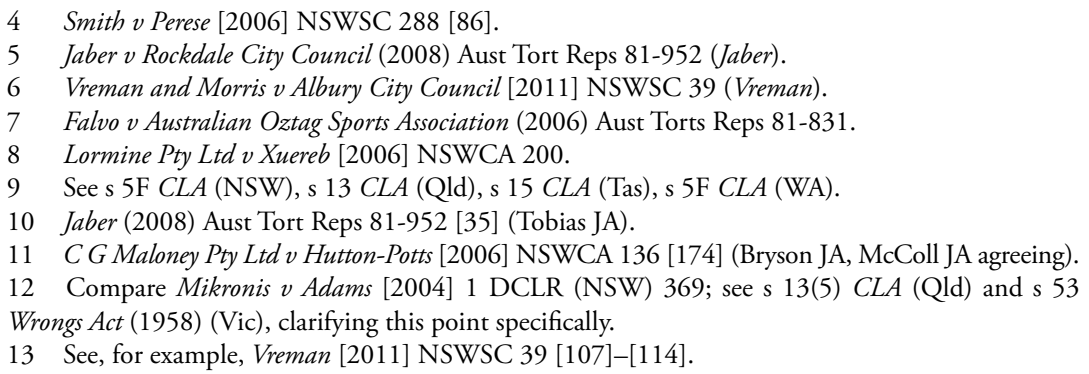


The upshot of this is that the law that governs claims by persons injured in recreational activities in one jurisdiction will differ to that which applies to persons injured in another and will depend on difficult statutory interpretation issues in some jurisdictions.

But what of the situation where a person is injured as a result of a negligently performed contract of recreational services, or indeed, services more generally, and therefore the $A C L$ applies?

\section{III. $A C L$ and Inconsistent Consumer Protection}

The new $A C L$ came into effect on 1 January 2011. Its stated aim was to 'create a single national consumer law'. ${ }^{14}$ There are, however, exceptions to this uniformity. The $A C L$ is the result of a complex exercise of cooperative federalism, with the Competition and Consumer Act 2010 (Cth) (CCA) inserting the $A C L$ as Sch 2 of the CCA. Part XIAA of the $C C A$ provides for the application of the $A C L$ as a law of the states and territories. ${ }^{15}$

Commonwealth jurisdiction applies (s 131 CCA) where a consumer enters into a contract with a 'corporation', as defined in $s 4$ and as extended by s 6 to natural persons in certain defined contexts. ${ }^{16}$ Hence, if a 'corporation' (in its extended sense) supplies services in trade and commerce to a consumer, it is bound by the $A C L$ as a law of the Commonwealth via s 131 and $\mathrm{Pt} \mathrm{XI}$ of the CCA. In relation to natural persons, the applicable law is that of the relevant state jurisdiction in which the services were supplied. State provisions also apply to corporations, of course, so long as they are not inconsistent with Commonwealth law. If the $A C L$ were truly uniform, it would not matter which jurisdiction, Commonwealth or state, applied or, in the latter case, which state law applied. However, the $A C L$ is not uniform. Importantly, the $A C L$ 's uniformity is seriously undermined in the context of a failure to comply with the guarantee that services are supplied with due care and skill, where such failure results in personal injury or property damage.

14 Commonwealth, Explanatory Memorandum to Trade Practices Amendment (Australian Consumer Law) Bill No 2 (2010) 3.

15 All jurisdictions have applied the $A C L$ under their relevant Fair Trading Acts. See, for example, Fair Trading Act 1987 (NSW) Pt 3, Div 2, inserted by the Fair Trading Amendment (Australian Consumer Law) Act 2010 (NSW).

16 See para 6(2)(c). 
Section 60 of the $A C L$ provides: 'If a person supplies, in trade or commerce, services to a consumer, there is a guarantee that the services will be rendered with due care and skill'. A consumer who suffers 'reasonably foreseeable' personal injury or property damage as a result of a careless supply of services can seek damages under s 267. For example, if a climbing instructor fails properly to instruct the client on the use of safety gear so that the client falls and suffers injury or (to take a nonrecreational example) a mechanic carelessly repairs a car, causing brake failure, the client has a potential claim for damages under s 267 .

Where a claim is brought under the $A C L$, the state CLAs continue to apply in relation to establishing the legal requirements for liability, any applicable defences, and the applicable principles for calculating damages (including the various limits contained in the CLAs). This is because, first, the CLAs set out general principles applying to claims arising from a failure to take reasonable care, irrespective of whether such claims are brought in tort, contract or under statute $;^{17}$ and second, and importantly, s $275 A C L$ allows for the continued operation of state laws that apply to the careless supply of services under a contract.

Section 275 is a complex section, and all of the difficulties that it raises cannot be explored here. To simplify, the effect of the section appears to be to engage any law, of the state that is the relevant 'proper law of the contract', ${ }^{18}$ which law 'applies to limit or preclude liability' under a claim on the contract. Consequently, provisions of the various CLAs that directly limit or preclude liability for careless conduct will be effective and applicable. According to the High Court in Insight Vacations Pty Ltd $v$ Young, ${ }^{19}$ a case concerning the (almost identically worded) ${ }^{20}$ equivalent s 74(2a) under the previous Trade Practices Act (TPA), s 74(2A) operated to pick up and apply 'as surrogate federal law' $^{21}$ a state law that of itself

17 See, for example, CLA (NSW) s 5A; CLA (Qld) Ch 2, Pt 1 (most sections apply to 'breach of duty of care', defined to include claims in contract or under statute, though Div 4 on dangerous recreational activities applies only to 'negligence', suggesting that breaches of contractual duties of care are not within the scope of the Division: see R J Douglas, G R Mullins and S R Grant, The Annotated Civil Liability Act 2003 (Qld) (LexisNexis, $3^{\text {rd }}$ edn, 2012) [19.5]).

18 One difficulty is that the proper law of the contract may not be the same as the place where the services are provided, but it is unlikely that the CLAs have extra-territorial operation: cf Insight Vacations Pty Ltd v Young (2011) 243 CLR 149 [35].

19 (2011) 243 CLR 149 (Insight).

20 This is apart from seemingly minor changes to the wording to reflect the change from implied terms to statutory guarantees.

21 Insight (2011) 243 CLR 149 [12]. 
applies to limit or preclude liability. ${ }^{22}$ In other words, s 74(2A) allowed state laws to directly limit rights of consumers via the CLAs; that is, it picked up, for example, sections in some states that deal with DRAs. ${ }^{23}$

Assuming that s $275 A C L$ has a similar effect as s $74(2 \mathrm{~A}) T P A$, then important consequences follow for the overall scheme of the $A C L$. As a result of s 275 , some differing state provisions that determine liability for personal injury suffered as a result of carelessness continue to operate in each jurisdiction. These would apply equally to corporate (defendant) suppliers. Some of the key inconsistencies arising between jurisdictions include:

1. Different state laws place different limitations on various heads of personal injury damages. This is a complex patchwork of rules that applies where state jurisdiction is activated; where Commonwealth jurisdiction applies, Pt VIB CCA has similar limitations.

2. Some specific defences adopted in some jurisdictions, including perhaps those dealing with recreational activities, continue to operate via s $275,{ }^{24}$ as noted above. For example, if a consumer of a supplier of services is injured while engaged in a DRA, the supplier of such services can potentially defend such a claim on that basis in NSW, even where such a supplier was negligent, ${ }^{25}$ whereas a supplier in Victoria could not.

3. Apart from defences concerning recreation, other defences have been adopted in some jurisdictions and not others, such as those dealing with intoxicated plaintiffs.

The consistent treatment within states of all claims for carelessly caused injuries leads to inconsistency and lack of uniformity between different states. This lack of uniformity arises for some provisions even if Commonwealth

22 Ibid. [12], [35]-[36] (French CJ, Gummow, Hayne, Kiefel and Bell JJ).

23 See for more detailed discussion of these issues, see J Dietrich, 'Liability for Personal Injuries from Recreational Services and the New Australian Consumer Law' (2011) 19 Torts Law Journal 55; and 'Service Guarantees and Consequential Loss under the ACL: The illusion of uniformity' (2012) 20 Competition \& Consumer Law Journal 43.

24 Admittedly, however, restrictions on liability that are picked up by s 275 include even general defences, such as contributory negligence and voluntary assumption of risk, which are probably only effective as a result of $s 275$.

25 The DRA defences are picked up because the provisions 'limit' liability. However, s 5M CLA (NSW) is not picked up, as it states that no duty arises at all (rather than limits liability for a duty that has been breached): see Motorcycling Events Group Australia Pty Ltd v Kelly [2013] NSWCA 361 [87][96] (Motorcycling). This case also highlights numerous other complex issues, not herein considered, that arise from the interaction between state and Commonwealth law. 
jurisdiction applies. Why the legislatures have not considered uniformity to be desirable given such potentially serious consequences is puzzling. Ultimately, that lack of uniformity is a result of politics and the failure of the states to agree on a uniform $C L A$ regime, and that was and remains a regrettable state of affairs.

\section{Exclusion of Liability}

A further area in which reform is needed concerns the law on exclusion of liability for failure to comply with the statutory guarantees. The statutory guarantees cannot generally ${ }^{26}$ be excluded by a supplier of services as a result of s $64 A C L$ : such a term is void if it seeks to exclude, restrict or modify the rights conferred and liabilities imposed under the consumer guarantees. Critically, however, it is possible under the $C C A$ for a supplier to exclude liability for failure to comply with the guarantees in the supply of recreational services. Section 139A CCA replicates the previous s $68 \mathrm{~B}$ $T P A$, which aimed to 'permit self-assumption of risk by individuals who choose to participate in inherently risky activities'. ${ }^{27} \mathrm{~A}$ term excluding liability for breach of s $60 \mathrm{ACL}$ guarantee is not void under s 64 if it 'excludes, restricts or modifies' such a statutory guarantee (s 139A(1)), for death or physical or mental injury (and not for property damage, for example). The definition of recreational services is broad (and not identical to that in various state CLAs).

Importantly, s 139A(4) does not allow for the exclusion of liability for reckless conduct, defined in subs (5). If an exclusion clause effectively excludes liability for conduct contravening s 60 , it will almost certainly also exclude liability for any negligence claims in tort as between the parties to the contract. If an exclusion clause is not effective in excluding liability for contravention of $s 60$, then a claim for damages for loss arising from contravention of $s 60$ (and presumably also in tort) will be available against a defendant service-provider.

Although the purpose of s 139A is clear enough, for a lawyer advising a client as to whether a clause effectively operates to exclude a claim the question is fraught with legal difficulties including:

26 Note, however, s 64A(2) ACL.

27 Explanatory Memorandum provided with the Trade Practices Amendment (Liability for Recreational Services) Bill 2002. 
1. Section 139A does not set out how an exclusion clause is to be effectively worded and incorporated into a service contract. This means that the important question of the effectiveness of an attempted exclusion of liability is determined by the vagaries of the labyrinthine common law contract principles on the incorporation of terms and their interpretation.

2. An exclusion clause that purports to exclude liability in broader terms than is permitted under $s$ 139A (e.g. for recklessness) may be void, ${ }^{28}$ even if the injury sustained comes within the permitted exclusions (e.g. if caused by ordinary negligence).

3. Adding to the complexity, s 139A CCA introduces a new distinction, between ordinary negligence, which can be excluded, and 'recklessness', which cannot. Obviously, this restriction has merit, in that it precludes the most serious carelessness from going unremedied; but it adds a new complication to the law by creating degrees of negligence.

4. An exclusion clause that purports to exclude liability in wider terms than is permitted is void, but the presence of such a void clause may mislead consumers into thinking that their rights are more limited, and may thus amount to misleading conduct under s 18 ACL. ${ }^{29}$

5. Section 139A raises a nuanced question of possible inconsistency between state and Commonwealth law, since Victoria has legislated to allow for the exclusion of liability for non-compliance with the statutory guarantees ${ }^{30}$ in narrower terms, that is, that are more onerous in setting out how a supplier can exclude liability. Does s 275 $A C L$ pick up the Victorian legislation or is there an inconsistency such that $s$ 139A will prevail? ${ }^{31}$

6. The legal effect of exclusion clauses that purport to bind minors is not adverted to in s 139A, yet the law on this is uncertain and in a confused state. ${ }^{32}$ This is so despite the widespread use of such clauses. The confusion arises because of the fundamental common law principle that minors do not have contractual capacity, such

28 Under the previous and differently worded s 68B TPA, such clause was void if it exceeded the permitted exclusions: see Motorcycling [2013] NSWCA 361. The different wording of s 139A CCA leaves the question in doubt.

29 And see s 29(1)(m) and (n) $A C L$.

30 See Dietrich, above $\mathrm{n} 23$.

31 Insight (2011) 243 CLR 149 does not deal with this because it deals with the indirect exclusion of liability in broader circumstances than permitted by Commonwealth law.

32 See generally, J Dietrich, 'Minors and the Exclusion of Liability for Negligence' (2007) 15 Torts Law Journal 87. 
that contracts entered into by minors, except for 'necessaries', are unenforceable against them; and nor do guardians have a general power to contract on minors' behalf.

\section{Reform}

The hope of a simplified and uniform regime of liability for personal injuries sustained during performance of a service contract has not been achieved. Obviously, the best solution to this problem would be for the states to reach agreement on a uniform civil liability regime, but the likelihood of this occurring in the medium-term future appears remote given that the $A C L$ process itself has not resulted in uniform solutions. At the very least, we need to reopen debate about our consumer protection laws and consider the competing policies that are at stake here. Key issues in this debate include: whether the desirability of uniformity is trumped by the desire (of some state legislatures) to enhance the assumption of 'self-responsibility'; the value of having a national injury compensation law; the need for clarity for consumers as to their rights (e.g. as to how and when exclusion clauses are effective); and, particularly, the need to protect minors from unfair and one-sided contractual provisions. 
This text is taken from New Directions for Law in Australia: Essays in Contemporary Law Reform, edited by Ron Levy, Molly O’Brien, Simon Rice, Pauline Ridge and Margaret Thornton, published 2017 by ANU Press, The Australian National University, Canberra, Australia. 